\title{
The sale catalogue of Sir Robert Sibbald's last library
}

Sir Robert Sibbald was the prime mover in the foundation of the Royal College of Physicians of Edinburgh in 1681. One year later, Sibbald donated 'three shelfes full of books to the Colledge of Physitians', thus founding the College Library, the first in Scotland specifically intended for the study of medicine.

Sibbald was a considerable collector of books and, after his death in August 1722, the sale of his last library (he had previously lost many of his books in a fire) attracted considerable interest. His books were sold at auction in Edinburgh by the Edinburgh bookseller William Brown on 5 February 1723. A catalogue for the sale was printed, which was sold 'for a sixpence each' at Brown's bookshop and other Edinburgh booksellers. Copies of the catalogue survive including two copies in the College Library - in which the prices achieved at the sale have been annotated. In one of the College's copies these annotations are much neater and more legible than in many of the other surviving copies.

Although the catalogue is not impressive as a book - it is rather roughly printed on poor paper - it contains a wealth of information about Sibbald's library and is of general interest as an example of a professional gentleman's library in the early eighteenth century.

The modern reader is at once struck by the arrangement of the books, which is quite unlike that in modern catalogues. Sibbald's books are arranged in sections of broad subject groups named in Latin: theological books come first, followed by geography, history and politics in the next group, then medicine, pharmacy and surgery, followed in turn by natural history, botany, philosophy and mathematics, then, finally for the printed books, Scripti Graeci \& Latini, Antiquarii \& Misc - that is, copies of classical literary works and commentaries on them and on similar topics. Within each of the broad groups the books are arranged in subsections by format: folio first, then quarto, then octavo et infra (octavo and smaller formats). But within the subsections the individual works appear in no discernible order.

The sale took place in Sibbald's house and we do not know how the books were presented - it is possible that they were sold directly from the shelves, in which case the catalogue order may be the order in which the books were shelved, or the order in which they were lifted from the shelves.
The arrangement is maddening: to find any title all the size divisions within the whole subject section have to be searched. And, if an author is sought, it may even be necessary to search through more than one subject. This process has to be repeated for each title or author. The College Library has now made an electronic catalogue from a transcription of the entries and this makes it practicable to ask - and answer - questions about the nature of Sibbald's final library. The process has only just begun and I shall only give a few examples.

There are 5,174 printed books by my reckoning, based on the serial numbering of the catalogue itself. These are followed by a collection of manuscripts which, the sale conditions warn, 'are to be exposed by whole-sale'; that is, they were to be sold as a single lot if possible, 'And if no Person offer for the whole they are to be exposed singly, or in Classes, as the Company shall determine.' In the event, all of Sibbald's manuscripts were purchased as a single lot by the Library of the Faculty of Advocates for ' $£ 260.0 .0$ ' (see Figure I). The sale conditions make it clear that the prices were in sterling, the official national currency after 1707. When, in the twentieth century, the non-legal collections of the Advocates' Library formed the basis of the National Library of Scotland (NLS), these manuscripts were among the papers deposited there, and there they remain.

Although it is frustrating for the reader, the listing of the books by size allows us to compare the relative frequency of formats in this quite substantial collection. For all subject groups, there were more small formats (octavo et infra) than quartos, and the folios were the fewest. Overall there were 2,994 books in octavo or smaller, I,316 quartos and 864 folios. The development of roman types legible in small sizes during the sixteenth

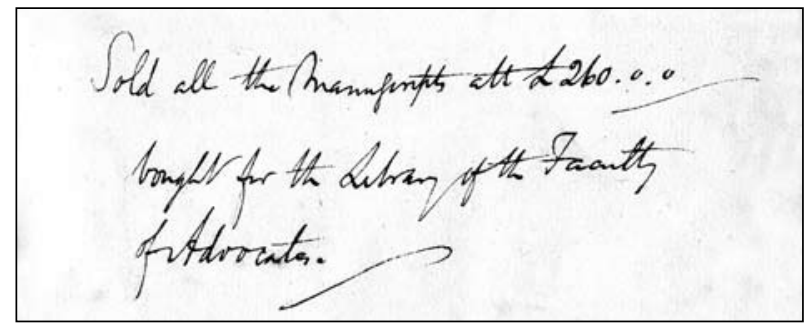

FIGURE I The manuscript note of the sale of all of Sibbald's manuscripts to the Advocates' Library. 


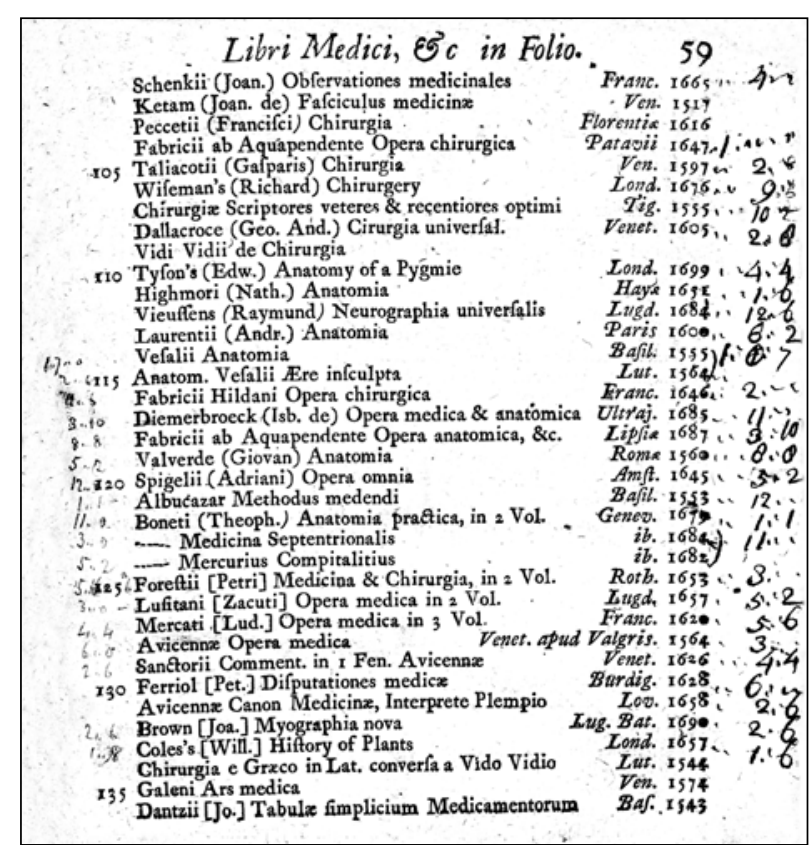

FIGURE 2 Page 59 of the catalogue showing some of the titles of the medical folios with the prices they fetched (right margin). See particularly lines II4 and II5.

century had led to a gradual increase in the proportion of books published in small formats, in which the small type allowed an increase in the content per page and so a reduced number of pages. A very substantial part of the cost of books in the hand-press period was the cost of the paper. Thus small type in small formats meant reduced production cost as well as greater portability. The make-up of Sibbald's collection thus reflects a process that had been in progress for some time.

The proportion of the subjects in the collection may come as a surprise to modern doctors. Sibbald had more works of, and on, classical literature $(1,486)$ and on geography and history $(1,189)$ than on medicine (799) and natural history (662). Of course, before drawing conclusions about the extent to which this reflects his own tastes - as, naturally, it must to some extent - one would need to consider the relative availability of works in different spheres of knowledge in the later seventeenth and early eighteenth centuries. There is also the question of how much the make-up of the collection reflects the taste of the age as well as the taste of its owner.

But it cannot be doubted that, even had Sibbald read only a proportion of the books in his library, he must have been both well-read and well-informed in most of the fields of knowledge and of literature that were available.

The annotations allow us to ask some questions about the relative 'value' of various books. Of course, at any sale, the price paid reflects value only in the sense of demand for that book from that audience on that day. That said, we may consider a couple of examples. Two of the most expensive books, at $£ 4-5 /-$ and $£ 4-10 /$ - respectively, are described as 'Stephani (Rob.) Thesaurus Linguæ Latinæ Paris I536' and 'Stephani (Henr.) Thesaurus Linguæ Græcæ, cum Append. 4 Vol- Apud H. Steph'.

The first book is the great Latin dictionary of Robert Estienne the first, compiled, printed and published by himself. The second is Henri Estienne the second's Greek/Latin thesaurus, compiled, printed and published in Geneva in 1572 by Robert's son. These two dictionaries compiled by two of the Estiennes, that great Parisian family of scholarly printers, were landmarks of Renaissance classical scholarship.

We may compare these to two medical books (see Figure 2) of which the Library has copies, although, sadly, not Sibbald's copies. The first of these is the second edition of Andreas Vesalius's Fabrica (Basel, 1555), described in line II 4 just as 'Vesalii Anatomia Basil. I555', which was sold in one lot with a book described in line I I 5 as 'Anatom. Vesalii Aere insculpta Lut. 1564'.

The second work is, in fact, the Anatomes totius, aere insculpta delineatio, a re-edition of the Epitome of Vesalius with a commentary by Jacques Grévin and illustrated with the copperplate engravings of Thomas Geminus, which André Wechel published in Paris in 1564. Together, the two books fetched $£ \mathrm{I}-0-7$; a respectable price at this sale but less than a quarter of that paid for the Latin and Greek dictionaries individually.

Attempts to express these prices as modern 'values' are hazardous. One pound and sevenpence in 1723 was 'worth' $£ \mid 50$ in 2008 based on the retail price index, or $f I, 534$ if a criterion based on average earnings is used. In fact, the current market value of each of these anatomical works individually is several tens of thousands of pounds. The 'worth' of the Latin and Greek dictionaries has fared less well. At the time of writing, a good complete copy of the 1572 edition of Henri Estienne's Greek thesaurus was on sale for less than $£ 5,000$.

This difference in the relative prices between the eighteenth century and the present is simply the result of changes in fashion; the Renaissance scholarship of the dictionaries - in many ways still unsurpassed - is now much less in demand than are copies of the (magnificently) illustrated anatomies which are their close contemporaries.

In this short piece I have only scratched the surface of the information waiting to be extracted from the sale catalogue of Sibbald's last library. Although his manuscripts remain together in the care of the NLS, his books, sadly, are scattered to the winds. Tantalisingly, the copy of the sale catalogue in the NLS marks some books with initials which may, perhaps, be those of their buyers, but I have not been successful in identifying these.

IML Donaldson, Honorary Librarian, RCPE (email: i.m.l.d@ed.ac.uk) 